\title{
PENGARUH EKSTRAK DAUN LIDAH MERTUA (Sansevieria trifasciata laurentii) TERHADAP KADAR HEMOGLOBIN TIKUS PUITH JANTAN (Rattus norvegicus strain wistar) YANG DIINDUKSI TIMBAL PER-ORAL
}

\author{
Rif'atul Ifada ${ }^{1}$, Diah Hermayanti ${ }^{2}$, Yuliono Trika Nur Hasan ${ }^{3}$ \\ Fakultas Kedokteran, Universitas Muhammadiyah Malang, \\ Jalan Bendungan Sutami 188A, Malang, 65145
}

\author{
Email : faa_rifa@ymail.com
}

\begin{abstract}
ABSTRAK
Logam berat timbal yang masuk kedalam tubuh dalam waktu singkat dan jumlah yang banyak dapat menyebabkan keracunan timbal sub-akut. Di sisi lain, daun Lidah Mertua (Sansevieria trifasciata laurenti) memiliki kandungan pregnane glycoside dan vitamin C sebagai antioksidan yang mampu mengikat logam berat timbal.Tujuan : Mengetahui pengaruh pemberian ekstrak daun Lidah Mertua (Sansevieria trifasciata laurentii) terhadap kadar hemoglobin pada tikus putih jantan (Rattus norvegicus starin wistar) yang telah diinduksi oleh timbal per-oral.Metode Penelitian : Penelitian ini menggunakan desain True Experimental Post Test Only Group Design. Penelitian ini dilakukan selama 15 hari dengan lima kelompok tikus, yaitu kelompok tanpa perlakuan (K-), kelompok yang diinduksi timbal saja $(\mathrm{K}+)$, kelompok P1, P2, dan P3 yang diberi ekstrak daun Lidah Mertua dengan dosis 8,$3 ; 41 ; 83 \mathrm{mg} / \mathrm{kgBB} /$ hari, kemudian dilakukan induksi timbal menggunakan larutan timbal asetat dosis $15 \mathrm{mg} / 100 \mathrm{gBB} /$ hari. Pengambilan sampel darah tikus melalui ventrikel kemudian dilakukan uji kadar hemoglobin menggunakan metode cyanomethemoglobin.Hasil Penelitian dan Diskusi : Hasil penelitian 4 minggu didapatkan rerata hemoglobin kelompok K- adalah 12,98 g/dL, kelompok $\mathrm{K}+$ adalah 13,18 g/dL, kelompok P1 adalah 12,16 g/dL, kelompok P2 adalah 12,64 g/dL, dan kelompok P3 adalah 12,96g/dL. Setelah diuji komparasi oneway ANOVA didapatkan nilai signifikansi $0,521>\mathrm{p}(0,05)$ yang berarti penelitian ini tidak terdapat perbedaan bermakna antara kadar hemoglobin pada seluruh kelompok.Kesimpulan : Pemberian ekstrak daun Lidah Mertua (Sansevieria trifasciata laurentii) tidak berpengaruh terhadap peningkatan kadar hemoglobin tikus putih jantan (Rattus norvegicus strain wistar) yang diinduksi timbal per-oral.
\end{abstract}

Kata Kunci : Sansevieria trifasciata laurentii, Mother in Law Tongue Leaves, plumbum, hemoglobin level.

\begin{abstract}
Metal plumbum that entry intro the body in short time and in subtantial amount can cause sub-acute lead poisoning. Meanwhile, Mother in Law Tongue Leaves (Sansevieria trifasciata laurentii) contained pregnande glycoside and vitamin $C$ as antioxidant that can adsorb metal plumbum.Objective: This experiment to find the effect of Mother in Law Tongue Leaves (Sansevieria trifasciata laurentii) extract to hemoglobyn level in male rat blood (Rattus norvegicus strain wistar) that induced by orally plumbum intervention. Methode : The method was True Experimental Post Test Only Group Design for 15 days. There were five groups of rats: without intervention of plumbum and extract (K-); Pb-only intervention (K+), group P1, P2, and P3 intervented by Mother in Law Tongue Leaves (Sansevieria trifasciata laurentii) extract for each group sequentially was 8.3; 41;83 $\mathrm{g} / \mathrm{KgBB}$, then induced by plumbum use plumbum acetate solution was 15 $\mathrm{mg} / 100 \mathrm{gBB}$. Then, rat blood from ventricle is tested by using cyanomethemoglobin methode for hemoglobin level.Result and Discuss : The experiment result showed mean hemoglobin from $\mathrm{K}$ - group was $12.98 \mathrm{~g} / \mathrm{dL}, \mathrm{K}+$ group was $13.18 \mathrm{~g} / \mathrm{dL}, \mathrm{P} 1$ group was $12.16 \mathrm{~g} / \mathrm{dL}, \mathrm{P} 2$ group was $12.64 \mathrm{~g} / \mathrm{dL}$, and P3 group was $12.96 \mathrm{~g} / \mathrm{dL}$. After that, tested with oneway ANOVA was 0,521 > p (0,05), it was mean that there was not sigficant different among hemoglobyn level in every group.Conclusion : Giving of Mother in Law Tongue Leaves (Sansevieria trifasciata laurentii) didn't affect to increase hemoglobin level of male rats (Rattus norvegicus strain wistar) induced by orally plumbum intervention.
\end{abstract}

Keywords : Sansevieria trifasciata laurentii, Mother in Law Tongue Leaves, plumbum, hemoglobin level. 


\section{PENDAHULUAN}

Timbal atau disebut juga sebagai timah hitam merupakan salah satu logam berat beracun dan berbahaya. Timbal banyak ditemukan sebagai pencemar dan cenderung mengganggu kelangsungan hidup organisme perairan. Timbal yang masuk ke dalam perairan dapat berasal dari limbah industri kimia, industri percetakan serta industri yang menghasilkan logam dan cat. Sehingga akibat dari pencemaran perairan ini dapat mengakibatkan timbal terakumulasi pada ikan. Disisi lain, ikan merupakan salah satu dari makanan manusia sehingga timbal yang terakumulasi pada ikan dapat terdistribusi ke tubuh manusia.(Aunurobim, Yulaipi S, 2013) Sehingga, sekitar 65\% timbal dapat masuk ketubuh manusia melalui makanan, 20\% melalui air, serta 15\% melalui udara.(Batubara I, Latifah K D, Lela M Y, 2014)

Kriteria diagnosis peningkatan kadar timbal dalam darah untuk orang dewasa ( ${ }^{3} 16$ tahun) menurut Clinical Laboratory Improvement Amendments (CLIA) adalah ${ }^{3} 5 \mathrm{mg} / \mathrm{dL}(0,24 \mathrm{mmol} / \mathrm{L}) \cdot{ }^{3} \mathrm{CDC}$, 2016 Kadar timbal yang melebihi Nilai Ambang Batas (NAB) dapat menyebabkan gangguan pada tubuh manusia, salah satunya gangguan pada hemoglobin. Selain itu, timbal di dalam darah merupakan radikal bebas yang mengakibatkan kadar ROS (Reative Oxygen Species) meningkat sehingga dapat merusak membran sel yang mengandung lipid salah satunya sel darah merah. Pada kerusakan membran sel darah merah dapat menyebabkan hemolisis dan penurunan kadar Hb. ${ }^{4}$ Djokomoejanto, Ag S, Iswari S et al, 2012 Selain itu, timbal juga dapat menghambat enzim ALAD (Asam äAminolevulinat Dehidrase) dan ferrochelase pada proses pembentukan heme. (Hashemian $A$ H, Haji $A$ Y, 2013,Lubis B, Flora M P, Nelly $\mathrm{R}$ et al, 2013)

Tindakan medis untuk mengurangi efek toksik dari timbal adalah dengan terapi kelasi. Agen kelasi hingga saat ini memiliki harga yang sangat mahal, tidak tersedia secara kontinyu, tidak dapat diperoleh tanpa resep dokter, dan dalam jumlah yang mencukupi. Berdasarkan kendala tersebut, terapi kelasi pada manusia yang mengalami keracunan timbal tidak ditangani dengan cepat dan tepat. Sehingga penundaan terapi dapat berakibat fatal bahkan sampai terjadi kematian.(Andriyanto, Aulia A M, Ietje $W$ et al, 2014)

Lidah Mertua atau dikenal dengan nama ilmiah Sansevieria trifasciata laurentii memiliki kemampuan menyerap zat polutan berbahaya dikarenakan Lidah Mertua memliki bahan aktif Pregnane Glikoside, yang berfungsi untuk mereduksi polutan menjadi asam organik, gula dan asam amino, yang tidak berbahaya bagi manusia (Dewi Y S, Indri H, 2012), Selain itu juga memiliki antioksidan berupa vitamin $\mathrm{C}$ dan vitamin $\mathrm{E}$ yang dapat berpengaruh terhadap kuantitas hemoglobin dan efektif mengatasi radikal bebas timbal.(Cabyati $Y$, Didik R S, Roni P et al, 2014)

Pada penelitian yang telah dilakukan sebelumnya secara in-vitro terhadap limbah cair timbal dengan konsentrasi $0,1 \mathrm{M}$ sebanyak $5 \mathrm{ml}$ diperoleh hasil bahwa ekstrak daun Lidah Mertua dengan kepekatan 100\% sebanyak 5,5ml dapat menyerap $>80 \%$ timbal yang terkandung di dalamnya.(Kurniawan A F, Amirul M, Sri E L et al, 2013)

\section{TINJAUAN PUSTAKA}

\section{Lidah Mertua}

Klasifikasi Tanaman Lidah Mertua:

$\begin{array}{ll}\text { Kingdom } & \text { : Plantaeymax } \\ \text { Subkingdom } & \text { : Tracheobionta } \\ \text { Super Divisi } & : \text { Spermathophyta } \\ \text { Divisi } & : \text { Magnoliophyta } \\ \text { Sub Divisi } & : \text { Angiospermae } \\ \text { Kelas } & : \text { Monocotyledonae } \\ \text { Sub-kelas } & : \text { Lilidae } \\ \text { Ordo } & : \text { Liliales } \\ \text { Famili } & : \text { Agavaceae } \\ \text { Genus } & \text { : Sansevieria } \\ \text { Jenis } & : \text { Sansevieria trifasciata }\end{array}$

Daun Lidah Mertua mengandungan mengandung bahan aktif pregnane glikoside.(Dewi Y S, Indri $H$, 2012) Selain itu, Lidah Mertua juga mengandung senyawa lain yaitu carotenoids, phytates, saponins, dan tannins. Dalam penelitian lain juga disebutkan bahwa Lidah Mertua banyak mengandung vitamin C. Satu tanaman Lidah Mertua dewasa yang berdaun 4-5 helai dapat menyegarkan udara dalam ruangan seluas $20 \mathrm{~m}^{2}$.

\section{Timbal}

Timbal atau timah hitam $(\mathrm{Pb})$ adalah kelompok logam berat golongan IVA dalam sistem periodik unsur kimia yang memiliki nomor atom 82 dengan berat atom 207,2 dan memiliki berat jenis 11,4/L. Timbal juga memiliki empat bentuk isotop yang berwarna kebiru-biruan atau abu-abu keperakan dengan titik leleh pada $327,5^{\circ} \mathrm{C}$ dan titik 
didih pada $1.740^{\circ} \mathrm{C}$ di atmosfer. (Lubis B, Flora $M$ P, Nelly R et al, 2013)

Timbal yang diserap oleh tubuh, 99\% timbal akan terikat pada eritrosit, sehingga kadar timbal dapat diperiksa melalui darah (Lubis, Flora, Nelly et al, 2013). Timbal yang berada di dalam darah dapat mengganggu sistem hemopitik pada sintesa heme dengan dua mekanisme, yakni menggangu penyatuan Glycine dan Succinyl Co-Ensyme $A$ melalui depresi terhadap $\mathrm{d}$-aminolevulinat dehidrase (d-ALAD) serta mengganggu enzim Ferrochetalase yang berfungsi melekatkan besi $(\mathrm{Fe})$ terhadap protoporphyrin. Akibatnya, pembentukan heme menurun. (Lubis B, Flora M P, Nelly $\mathrm{R}$ et al, 2013)

Pemberian timbal asetat dapat menurunkan aktivitas enzim katalase yang bekerja untuk menetralisir oksidan hidrogen peroksida $\left(\mathrm{H}_{2} \mathrm{O}_{2}\right)$. $\mathrm{H}_{2} \mathrm{O}_{2}$ merupakan salah satu senyawa Reative Oxygen Species (ROS) yang dapat menyebabkan peroksidasi lipid dari asam lemak tak jenuh dengan tiga atau lebih ikatan rangkap. Sumber utama ROS adalah dari hasil respirasi seluler dan proses metabolisme. Sedangkan peroksida lipid merupakan hasil reaksi yang dicetuskan oleh logam timbal dalam bentuk ion dan berfungsi untuk memasok radikal bebas sehingga terjadi reaksi peroksida berikutnya. Radikal lipid akan bereaksi dengan oksigen membentuk radikal peroksi-lipid dan lipid peroksida serta malondialdehyde (MDA) yang larut dalam air dan dapat dideteksi dalam darah.

Selain itu, ROSmempunyai peran krusial pada proses patologis. ROS berperan dalam fungsi imun, tiroid, kognitif dan modulasi sensor nutrien dan umur. ROS juga berimplikasi pada beberapa penyakit antara lain cancer, penyakit kardiovaskuler (termasuk hipertensi), penyakit saraf, gangguan pernapasan dan penyakit psikiatrik. Peningkatan ROS dan MDA dapat menyebabkan kerusakan membran sel yang mengandung senyawa lipid termasuk eritrosit. Peroksidasi membran eritrosit menyebabkan hemolisis sehingga terjadi penurunan kadar Hb.(Djokomoejanto, Ag S, Iswari S et al, 2012)

Akumulasi timbal dalam tubuh dapat menyebabkan keracunan timbal akut dan kronis. Keracunan timbal akut dan subakut disebabkan dengan paparan dosisi yang relatif tinggi, waktu paparan yang relatif singkat dan efek yang ditimbulkan terjadi secara dramatis, seperti kematian tiba-tiba kram perut yang parah, anemia, perubahan perilaku, dan kehilangan nafsu makan. Sedangkan untuk keracunan timbal kronik disebabkan paparan timbal yang sedikit demi sedikit dalam jangka waktu yang lama serta gejala yang ditimbulkan tidak spesifik pada hampi semua sistem dalam tubuh. (Andriyanto, Aulia A M, Ietje $W$ et al, 2014)

\section{Hemoglobin}

Hemoglobin $(\mathrm{Hb})$ merupakan komponen utama eritrosit yang berfungsi mentransport oksigen dan karbondioksida. ${ }^{18}$ Sintesis $\mathrm{Hb}$ dimulai dari proeritoblas dan berlanjut sampai retikulosit membentuk sel darah merah (eritrosit). Tahap dasar pembentukan $\mathrm{Hb}$ dimulai dari suksinil-KoA yang telah dibentuk dalam siklus Krebs berikatan dengan glisin untuk membentuk molekul pirol. Kemudian, dari empat pirol bergabung untuk membentuk protoporfirin IX yang selanjutnya akan bergabung dengnan besi untuk membentuk beme. Akhirnya, setiap molekul heme bergabung dengan rantai polipeptida panjang atau disebut dengan globin sehingga menjadi rantai hemoglobin. Empat rantai hemoglobin akan berikatan longgar untuk membentuk molekul hemoglobin yang lengkap.

\section{Pengaruh Ekstrak Daun Lidah Mertua terhadap Kadar Hemoglobin}

Tanaman Daun Lidah Mertua mengandung senyawa aktif pregnane glikosid yang berfungsi untuk mereduksi polutan menjadi asam organik, gula dan asam amino, yang tidak berbahaya bagi manusia. Adapun polutan yang direduksi sekitar 107 polutan diantaranya ada asap rokok, limbah perak (Ag) dan timbal $(\mathrm{Pb})$. Sedangkan, enzim ALA dehidrase merupakan enzim yang peka terhadap inhibisi oleh timbal. Dengan metabolic breakdown yang dilakukan oleh senyawa aktif pregnane glikosid dianggap dapat mereduksi timbal di dalam tubuh. Sehingga enzim ALA dehidrase tidak terinhibisi dan produksi heme kembali baik. (Dewi Y S, Indri H, 2012)

Selain itu, antioksidan yang terdapat di dalam daun Lidah Mertua dapat menangkap radikal bebas yang ada di dalam tubuh. Beberapa senyawa antioksidan dapat ditemui pada vitamin $\mathrm{C}$ dan $\mathrm{E}$ yang dapat berpengaruh terhadap kuantitas hemoglobin dan efektif mengatasi radikal bebas.Vitamin $\mathrm{C}$ merupakan antioksidan kuat yang bekerja dengan mendonorkan elektron ke senyawa logam serta menyumbangkan elektron ke dalam reaksi biokimia intraseluler dan ektraseluler serta mampu menghilangkan senyawa oksigen reaktif di dalam sel. Sedangkan vitamin E merupakan vitamin 
yang larut dalam lemak dan berperan penting dalam mengatasi kerusakan radikal bebas. Peran vitamin $\mathrm{E}$ adalah mengendalikan peroksida lemak dengan menyumbangkan hidrogen dan menghambat aktivitas yang dilakukan oleh peroksida dalam perusakan sel akibat radikal bebas.

Kombinasi vitamin $\mathrm{C}$ dan $\mathrm{E}$ dosis tinggi sebagai antioksidan dapat menghentikan reaksi berantai radikal bebas dengan mengikat radikal bebas yang mempengaruhi sumsum tulang sehingga efek penurunan sistem hemopoetik dapat dicegah dan mencegah kerusakan sel-sel normal. Vitamin C dan E bekerja secara sinergis, saling menetralkan produk teroksidasi masing-masing vitamin. Vitamin $\mathrm{C}$ berperan penting dalam mempertahankan jumlah vitamin $\mathrm{E}$ di dalam sel dengan cara mendaur ulang radikal vitamin $\mathrm{E}$ menjadi bentuk yang tereduksi dan kerusakan DNA karena teroksidasi oleh vitamin $\mathrm{C}$ juga dapat dihambat oleh vitamin $\mathrm{E}$.

\section{BAHAN DAN METODE}

\section{Jenis Penelitian}

Penelitian ini merupakan penelitian True Experimental dengan menggunakan metode The Post Test Only Control Group Design.

\section{Lokasi dan Waktu Penelitian}

Penelitian ini dilaksanakan selama 4 minggu di Laboratorium Biomedik Fakultas Kedokteran Universitas Muhammadiyah Malang dan di Laboratorium Patologi Klinik Fakultas Kedokteran Universitas Brawijaya.

\section{Populasi}

Populasi dalam penilitian ini adalah tikus putih jantan (Rattus norvegicus strain wistar).

\section{Sampel}

Sampel yang digunakan adalah tikus putih jantan (Rattus norvegicus strain wistar) dengan berat badan antara 180 - 240 gram dan berusia $2-3$ bulan dengan kondisi sehat yang ditandai dengan gerakan aktif serta mata yang jernih.

\section{Alat Penelitian}

Alat pembuatan ekstrak daun Lidah Mertua, antara lain: blender, timbangan analitik, corong, erlenmeyer, gelas ukur, oven, labu ukur, rotavator, ayakan mesh 200.
Alat pembuatan larutan timbal, antara lain: tabung labu, timbangan, botol, batang pengaduk.

Alat pemeliharaan tikus, antara lain: kandang tikus, penutup kandang dari anyaman kawat, botol air, timbangan, tempat makan tikus, sarung tangan.

Alat pembedahan tikus, antara lain: gunting bedah, pinset, tempat darah (botol sediaan), handscoon, pengait jaringan, jarum, spuit injeksi 3 $\mathrm{ml}$.

Alat analisis hemoglobin yaitu sprektofotometer.

Alat lain, antara lain: sonde modifikasi, kamera digital, kertas, alat tulis, kalkulator.

\section{Bahan Penelitian}

Bahan pembuatan ekstrak daun Lidah Mertua, antara lain: daun Lidah Mertua, kertas saring, metanol.

Bahan pembuatan larutan timbal, antara lain: kristal timbal asetat $\left(\mathrm{Pb}\left(\mathrm{CH}_{3} \mathrm{COO}\right)_{2}\right)$ dan aquades.

Bahan perawatan tikus, antara lain: pakan ternak, air minum, sekam.

Bahan analisis hemoglobin, antara lain: reagen cyanomethemoglobin.

\section{Pembuatan Ekstrak Daun Lidah Mertua}

Daun Lidah Mertua (Sansevieria trifasciata laurentii) dicuci bersih dibawah air mengalir, ditiriskan, dipotong-potong dan dikeringkan dengan cara diangin-anginkan tanpa terkena sinar matahari langsung selama 4 jam. Selanjutnya, dikeringkan dalam oven pada suhu $50^{\circ} \mathrm{C}$ kemudian dihaluskan menggunakan blender dan diayak menggunakan ayakan mesh 200 sehingga diperoleh serbuk simplisia. Serbuk simplisia daun Lidah Mertua sebanyak 50 gram direfluks dengan metanol (1:10) selama 30 menit. Sari metanolik dipisahkan dari ampas dan diuapkan menggunakan rotavator hingga kental.

\section{Penentuan Dosis Ekstrak Daun Lidah Mertua}

Dosis ekstrak daun Lidah Mertua yang digunakan pada penelitian ini mengikuti penelitian sebelumnya yang dilakukan oleh Laimeheriwa, Adeanne, Widya tahun 2015 pada penelitiannya yang berjudul "Uji Efek Ekstrak Etanol Daun Lidah Mertua terhadap Penurunan Kadar Gula 
Darah Tikus Putih Jantan Galur Wistar yang diinduksi Sukrosa" dengan dosis $8,3 \mathrm{mg} / \mathrm{kgBB}$ dan $83 \mathrm{mg} / \mathrm{kgBB}$, serta di ambil dosis tengah diantara keduanya $41 \mathrm{mg} / \mathrm{kgBB}$.

\section{Pembagian Kelompok Tikus}

a. Kelompok kontrol negatif (K-) : diberi pakan standar tanpa diberikan larutan timbal per-oral serta tanpa pemberian ekstrak daun Lidah Mertua selama 15 hari.

b. Kelompok kontrol positif $(\mathrm{K}+)$ : diberi pakan standar dan diberi larutan timbal $15 \mathrm{mg} / 100 \mathrm{~g}$ BB per-oral dengan sonde tanpa diberi ekstrak daun Lidah Mertua selama 15 hari.

c. Kelompok Perlakuan 1 (P1) : diberi pakan standar dan ekstrak daun Lidah Mertua dengan dosis $8,3 \mathrm{mg} / \mathrm{kgBB}$ dan dilanjutkan dengan pemberian larutan timbal 15mg/100 g BB peroral dengan sonde selama 15 hari.

d. Kelompok Perlakuan 2 (P2) : diberi pakan standar dan ekstrak daun Lidah Mertua dengan dosis $41 \mathrm{mg} / \mathrm{kgBB}$ dan dilanjutkan dengan pemberian larutan timbal $15 \mathrm{mg} / 100 \mathrm{~g} \mathrm{BB}$ peroral dengan sonde selama 15 hari.

e. Kelompok Perlakuan 3 (P3) : diberi pakan standar dan ekstrak daun Lidah Mertua dengan dosis $83 \mathrm{mg} / \mathrm{kgBB}$ dan dilanjutkan dengan pemberian larutan timbal $15 \mathrm{mg} / 100 \mathrm{~g}$ BB peroral dengan sonde selama 15 hari.

\section{Persiapan Hewan Coba}

Tiga puluh ekor tikus jantan dipilih dan dipelihara selama 1 minggu sebagai tahap penyesuaian terhadap lingkungan. Pakan tikus yang diberikan adalah pakan standar dan minum diberikan secara ad libitum. Selain itu, pada masa adaptasi ini dilakukan penimbangan berat badan tikus. $^{26}$

\section{Pemberian Ektrak Daun Lidah Mertua}

Ekstrak daun Lidah Mertua diberikan selama 15 hari melalu sonde modifikasi. Dosis pemberian ekstrak daun Lidah Mertua yang diberikan yaitu:
Dosis I
: $8,3 \mathrm{mg} / \mathrm{kgBB}$
Dosis II
: $41 \mathrm{mg} / \mathrm{kgBB}$
Dosis III
: $83 \mathrm{mg} / \mathrm{kgBB}$

\section{Pemberian Larutan Timbal}

Pemberian paparan timbal dilakukan dengen mencekok tikus percobaan dengen timbal asetat yang sebelumnya telah dibuat dan disiapkan selama 15 hari dengan dosis $15 \mathrm{mg} / 100 \mathrm{~g}$ BB secara sonde pe-oral pada semua kelompok kecuali kelompok kontrol negatif. ${ }^{26}$

\section{Pembedahan Hewan Coba}

Pada tahap ini dilakukan dengan memasukkan hewan coba ke dalam toples kaca yang didalamnya telah diletakkan kapas yang mengandung kloroform. Pembiusan dilakukan satu persatu dengan harapan pembiusan dapat dilakukan secara inhalasi dengan dosis eter $0,67 \mathrm{~mL} /$ hewan coba selama \pm 60 detik. Selanjutnya, ketika hewan coba sudah teranastesi yang ditandai dengan tidak adanya respon nyeri, diletakkan pada meja paraffin dan keempat kaki tikus difiksasi menggunakan jarum pentul. Kemudian tikus dibedah menggunakan gunting dari abdomen hingga setinggi leher, kemudian faring dipenggang dengan pinset anatomis dan diiris menggunakan scapel. Setelah ditemukan jantung, ambil darah dari ventrikel kiri hewan coba dengan menggunakan spuit $5 \mathrm{cc}$.

Hewan coba yang telah dibedah, pastikan tidak mengalami recovery atau denyut nadinya sudah berhenti. Selanjutnya, dilakukan proses penguburan dengan cara tikus dibungkus menggunakan polybag, lalu dimasukkan kedalam lubang pada tanah kering dengan kedalaman 1 meter dan jarak 250 meter dari sumber air serta masing-masing lubang tidak lebih dari sepuluh ekor tikus.

\section{Pemeriksaan Kadar Hemoglobin}

Pengukuran kadar Hemoglobin menggunakan metode cyanomethemoglobin. Darah sebanyak $20 \mathrm{~mL}$ dicampur ke dalam $5 \mathrm{~mL}$ reagen cyanomethemoglobin lalu dihomogenkan. Nilai absorbansnya dibaca dengan menggunakan spektrofotometer dengan panjang gelombang 540 $\mathrm{nm}$. Perhitungan kadar hemoglobin dilakukan dengan mengalikan nilai absorbans dengan $368 \mathrm{~g}$ $\mathrm{Hb} / 100 \mathrm{~mL}{ }^{26}$

\section{HASIL DAN PEMBAHASAN}

Berdasarkan penelitian yang dilakukan selama 4 minggu dengan menggunakan tikus putih jantan (Rattus norvegicus strain wistar) pada lima kelompok 
yaitu kontrol negatif (K-), kontrol positif $(\mathrm{K}+)$ yang hanya di berikan larutan timbal asetat $15 \mathrm{mg}$ / $100 \mathrm{gBB}$, dosis ekstrak daun Lidah Mertua 8,3 mg/ $\mathrm{kgBB}$ (P1), $41 \mathrm{mg} / \mathrm{kgBB}$ (P2), dan $83 \mathrm{mg} / \mathrm{kgBB}$ (P3) serta dilanjutkan pemberian larutan timbal $15 \mathrm{mg} / 100 \mathrm{gBB}$ didapatkan hasil kadar hemoglobin (Hb) sebagai berikut.

Tabel 5 Hasil Kadar Hemoglobin Tikus Putih

\begin{tabular}{|c|c|c|c|c|c|c|}
\hline \multirow{2}{*}{$\begin{array}{l}\text { Kelo } \\
\text { mpok }\end{array}$} & \multicolumn{5}{|c|}{$\begin{array}{c}\text { Jumlah Kadar Hb Tikus } \\
\qquad(\mathrm{g} / \mathrm{dL})\end{array}$} & \multirow{2}{*}{$\begin{array}{c}\text { Rerata } \pm \\
\text { SD }(g / d L)\end{array}$} \\
\hline & 1 & 2 & 3 & 4 & 5 & \\
\hline K- & 12,8 & $\begin{array}{c}12 \\
8\end{array}$ & $\begin{array}{c}12, \\
6\end{array}$ & $\begin{array}{c}14, \\
7\end{array}$ & 12 & $\begin{array}{c}12,98 \pm \\
1,016\end{array}$ \\
\hline $\mathrm{K}+$ & 14,5 & $\begin{array}{c}11, \\
9\end{array}$ & $\begin{array}{c}12, \\
5\end{array}$ & $\begin{array}{c}14, \\
9\end{array}$ & $\begin{array}{c}12, \\
1\end{array}$ & $\begin{array}{c}13,18 \pm \\
1,411\end{array}$ \\
\hline P1 & 13,6 & $\begin{array}{c}11, \\
2\end{array}$ & $\begin{array}{c}13, \\
3\end{array}$ & $\begin{array}{c}12 \\
5\end{array}$ & $\begin{array}{c}10, \\
2\end{array}$ & $\begin{array}{c}12,16 \pm \\
1,436\end{array}$ \\
\hline P2 & 12,5 & $\begin{array}{c}11, \\
8\end{array}$ & $\begin{array}{c}13, \\
2\end{array}$ & $\begin{array}{c}12, \\
2\end{array}$ & $\begin{array}{c}13, \\
5\end{array}$ & $\begin{array}{c}12,64 \pm \\
0,702\end{array}$ \\
\hline P3 & 14,1 & $\begin{array}{c}13, \\
1\end{array}$ & $\begin{array}{c}12, \\
6\end{array}$ & $\begin{array}{c}12, \\
5\end{array}$ & $\begin{array}{c}12 \\
5\end{array}$ & $\begin{array}{c}12,96 \pm \\
1,100\end{array}$ \\
\hline
\end{tabular}

Berdasarkan tabel diatas diatas terlihat bahwa rerata kadar hemoglobin yang paling tinggi adalah kelompok $\mathrm{K}+$ yaitu $13,18 \mathrm{~g} / \mathrm{dL}$ dan rerata hemoglobin yang paling rendah adalah kelompok P1 yaitu 12,16 g/dL Berdasarkan hasil tersebut apabila dimasukkan kedalam grafik akan didapatkan bentuk sebagai berikut.

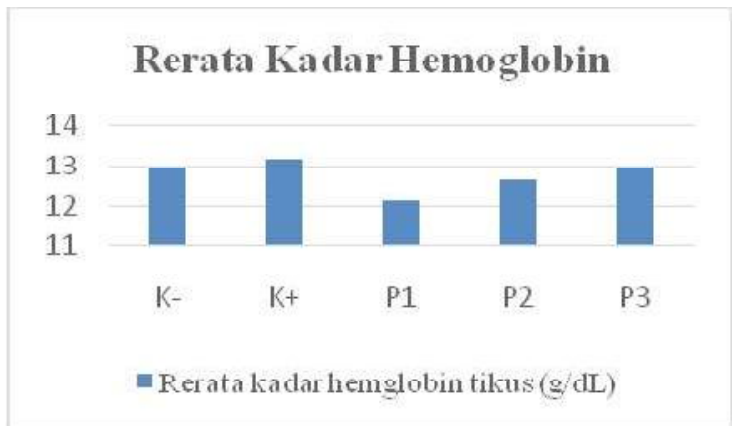

Gambar 5 Grafik Rerata Kadar Hemoglobin Tikus
Berdasarkan grafik diatas, diketahui bahwa pemberian larutan timbal asetat pada kelompok $\mathrm{K}+$ didapatkan rerata kadar hemoglobin 13,18 g/ $\mathrm{dL}$, dimana rerata tersebut lebih tinggi dibandingkan rerata dari kelompok K- yaitu 12,98 g/dL. Hal tersebut tidak sesuai dengan harapan peneliti bahwa apabila timbal berada di dalam darah maka terjadi gangguan sistem bemopitik pada sintesa beme serta mengganggu enzim Ferrochetalase yang berfungsi melekatkan besi $(\mathrm{Fe})$ terhadap protoporphyrin yang berakibat pembentukan heme menurun.

Penelitian sebelumnya tentang "Potensi Putih Telur Bebek dalam Mengatasi Keracunan Timbal Subakut" disebutkan bahwa pemberian timbal asetat sebesar $15 \mathrm{mg} / 100 \mathrm{~g}$ BB pada tikus putih putih jantan (Rattus norvegicus strain wistar) selama 15 hari menimbulkan gejala klinis berupa diare dan letargi. Tetapi dalam penelitian ini gejala klinis diare dan letargi tidak teramati oleh peneliti, hanya saja ada kemungkinan bahwa dalam penlitian ini terjadi gejala klinis yang sama yang dapat mengakibatkan terjadinya dehidrasi Pada kondisi dehidrasi terjadi penurunan volume total cairan tubuh sehingga terjadi pula penurunan volume cairan intrasel dan ekstrasel, salah satunya penurunan pada plasma darah. Dari penjelasan tersebut masih ada kemungkinan bahwa penurunan kadar hemoglobin tetap terjadi tetapi akibat penurunan plasma darah karena dehidrasi sehingga menutupi kondisi penurunan hemoglobin akibatnya nampak rerata kadar hemoglobin melebihi kelompok K-

Hasil uji homogenitas dalam penelitian ini didapatkan hasil tidak homogen, hal ini juga dapat menjadi salah satu penyebab tingginya rerata kadar hemoglobin dari kelompok K+. Data bersifat tidak homogen bisa disebabkan dari berbagai faktor, baik faktor endogen maupun faktor eksogen. Faktor eksogen adalah berupa kondisi lingkungan tikus sebelum menjadi hewan coba yang mungkin menyebabkan kadar $\mathrm{Hb}$ dalam masing-masing tikus tidak sama. Fakor eksogen ini telah diminimalisir oleh peneliti dengan memakai tikus dengan lingkungan yang sama dari peternakan tikus yang sama. Selain itu, kemampuan adaptasi dan asupan nutrisi dari makanan dan minuman tikus juga mempengaruhi kemampuan metabolisme untuk menangkal efek zat radikal bebas. Faktor ini juga telah diminimalisir oleh peneliti dengan mengontrol makanan dan minuman serta menempatkan tikus dalam kondisi lingkungan yang sama, baik dalam 
cahaya, suhu, maupun kelembaban. Sedangkan untuk faktor endogen antara lain, kemampuan absorbsi zat aktif daun Lidah Mertua pada saluran pencernaan tikus, kemampuan absorbsi terhadap larutan timbal asetat,atau senyawa antioksidan endogen. Namun, untuk faktor endogen ini tidak dapat diminimalisir oleh peneliti, sehingga diduga menjadi penyebab data bersifat tidak homogen.

Pada pemberian ekstrak daun Lidah Mertua (Sansevieria trifasciata laurentii) pada dosis $8,3 \mathrm{mg} /$ kgBB pada kelompok P1 didapatkan rerata kadar hemoglobin 12,16 g/dL, dosis $41 \mathrm{mg} / \mathrm{kgBB}$ pada kelompok P2 didapatkan rerata kadar hemoglobin $12,64 \mathrm{~g} / \mathrm{dL}$, dan dosis $83 \mathrm{mg} / \mathrm{kgBB}$ pada kelompok P3 didapatkan rerata kadar hemoglobin 12,96 g/dL. Dari hasil tersebut dapat dilihat bahwa terjadi peningkatan kadar hemoglobin pada masingmasing kelompok meningkat sesuai penambahan dosis ekstrak daun Lidah Mertua (Sansevieria trifasciata laurentii), hal ini sesuai dengan harapan peneliti bahwa dengan pemberian ekstrak daun Lidah Mertua (Sansevieria trifasciata laurentii) yang mengandung senyawa aktif pregnane glikosid yang mampu mereduksi polutan serta kandungan antioksidan seperti vitamin $\mathrm{C}$ dan $\mathrm{E}$ yang dapat berpengaruh terhadap kuantitas hemoglobin serta dapat mengatasi radikal bebas. Namun, jika dibandingkan dari masing-masing rerata kelompok P1, P2, dan P3 dengan rerata kelompok $\mathrm{K}+$ didapatkan rerata kelompok pemberian ekstrak Lidah Mertua (Sansevieria trifasciata laurentii) masih lebih rendah dibandingkan dengan rerata kelompok $\mathrm{K}+$. Hal ini diduga disebabkan pengaruh dari ekstrak daun Lidah Mertua (Sansevieria trifasciata laurentii) yang mereduksi polutan timbal sebelum mengakibatkan gejala klinis berupa dehidrasi yang dapat menutupi penurunan hemoglobin, sehingga tikus tersebut benar-benar mengalami penurunan hemoglobin. Selain itu, kandungan ekstrak daun Lidah Mertua (Sansevieria trifasciata laurentii) juga membantu dalam memperbaiki gangguan sistem hemopitik pada sintesa heme serta enzim Ferrochetalase yang berfungsi melekatkan besi (Fe) terhadap protoporphyrin yang diakibatkan oleh timbal sehingga seiring kenaikan dosis ekstrak daun Lidah Mertua (Sansevieria trifasciata laurentii) terjadi pula peningkatan kadar hemoglobin.

Hasil uji parametrik One Way ANOVA didapatkan nilai signifikasi $0,521>\mathrm{p}(0,05)$ yang berarti bahwa dalam penelitian ini tidak terdapat perbedaan bermakna antara kadar hemoglobin tikus putih jantan (Rattus norvegicus strain wistar) pada seluruh kelompok. Padahal, dari olahan data primer didapatkan bahwa pada kelompok P1, P2, dan P3 terjadi peningkatan kadar hemoglobin pada masingmasing kelompok meningkat sesuai penambahan dosis ekstrak daun Lidah Mertua (Sansevieria trifasciata laurentii), namun peningkatan ini tidak sejalan dengan hasil statistik yang didapatkan hasil tidak bermakna. Hal ini diduga disebabkan karena rentang dosis daun Lidah Mertua (Sansevieria trifasciata laurentii) yang digunakan pada penelitian ini terlalu sempit.

Berdasarkan olahan data primer yang telah dilakukan, penelitian ini memiliki beberapa kelemahan dan keterbatasan, diantaranya adalah kelemahan peneliti yang tidak memperhatikan adanya gejala klinis pada tikus putih jantan (Rattus norvegicus strain wistar) berupa diare dan letargi yang bisa menyebabkan penurunan hemoglobin tersamar akibat penurunan plasma darah akibat dehidrasi. Selain itu, kelemahan dan keterbatasan penelitian ini adalah dosis timbal yang diberikan terlalu sedikit sehingga efek penurunan hemoglobin hanya sedikit serta rentang dosis yang digunakan pada penelitian ini terlalu sempit dan belum memberikan hasil yang bermakna terhadap peningkatan kadar hemoglobin tikus putih jantan (Rattus norvegicus strain wistar).

Dari hasil analisis data yang diperoleh, maka hipotesis tentang pengaruh pemberian ekstrak daun Lidah Mertua (Sansevieria trifasciata laurentii) terhadap kadar hemoglobin tikus putih jantan (Rattus norvegicus strain wistar) yang diinduksi timbal per-oral adalah tidak terbukti. Pengaruh ekstrak daun Lidah Mertua (Sansevieria trifasciata laurentii) pada penelitian ini berupa pencegahan efek timbal terhadap pembentukan hemoglobin yang diperankan oleh pregnane glycosid dan vitamin $\mathrm{C}$ yang terkandung dalam ekstrak daun Lidah Mertua (Sansevieria trifasciata laurentii) tidak menimbulkan perbedaan yang bermakna pada peningkatan kadar hemoglobin tikus putih jantan (Rattus norvegicus strain wistar). Namun, masih diperlukan penelitian lebih lanjut tentang peningkatan pemberian dosis timbal asetat yang diberikan, variasi dosis ekstrak daun Lidah Mertua(Sansevieria trifasciata laurentii) dengan rentang yang lebih luas serta dosis toksik dari ekstrak daun Lidah Mertua (Sansevieria trifasciata laurentii). 


\section{KESIMPULAN DAN SARAN}

Berdasarkan hasil dan pembahasan pada penelitian ini dapat diambil kesimpulan sebagai berikut: Pemberian ekstrak daun Lidah Mertua (Sansevieria trifasciata laurentii) tidak pengaruh terhadap peningkatan kadar hemoglobin tikus putih (Rattus norvegicus strain wistar) yang diinduksi timbal peroral. Tidak ditemukan dosis efektif ekstrak daun Lidah Mertua (Sansevieria trifasciata laurentii) yang berpengaruh terhadap kadar hemoglobin akibat keracunan timbal. Peningkatan rerata kadar hemoglobin yang terjadi pada kelompok yang mendapat ekstrak daun Lidah Mertua (Sansevieria trifasciata laurentii) dengan dosis $8,3 \mathrm{mg} / \mathrm{kgBB}$ sebesar $12,16 \mathrm{~g} / \mathrm{dL}$, dengan dosis $41 \mathrm{mg} / \mathrm{kgBB}$ didapatkan hasil rerata kadar hemoglobin sebesar 12,64 g/dL, serta pada dosis $83 \mathrm{mg} / \mathrm{kgBB}$ didapatkan hasil rerata kadar hemoglobin sebesar 12,96g/dL.

Berdasarkan kesimpulan yang telah dikemukakan maka diberikan saran-saran yang dipergunakan dalam mengadakan perbaikan di masa yang akan datang, yaitu sebagai berikut: Perlu dilakukan penelitian pendahuluan tentang pengaruh timbal terhadap kadar hemoglobin tikus putih jantan (Rattus novergicus strain wistar). Perlu dilakukan penelitian lebih lanjut mengenai dosis ekstrak daun Lidah Mertua (Sansevieria trifasciata laurentii) dengan rentang terapi yang lebih lebar sertavariasi dosis yang lebih beragam dan konsisten untuk mencari dosis optimal untuk meningkatkan kadar hemoglobin darah tikus putih jantan (Rattus novergicus strain wistar) yang diinduksi timbal secara per-oral. Perlu dilakukan penelitian tentang dosis toksik dari ekstrak daun Lidah Mertua (Sansevieria trifasciata laurentii).

\section{DAFTAR PUSTAKA}

Adawiyah A R, Nia D A, Raisha S et al, 2013, Panda Sansevieria (Pengharum Ruangan Anti Debu dan Asap Rokok dengan Sistem Penetralsir Sirkulasi Udara), Jurnal Ilmiah Mahasiswa, vol. 3 no. 1, hal. $35-38$.

Alexandru I, 2011, Experimental Use of Animals in Research Spa, Balneo-Research Journal, vol. 2 no. 1 , hal. $65-69$.

Amin L Z, 2015, Tatalaksana Diare Akut, Continuing Medical Education, vol. 42 no. 7, hal. 504508.
Ambarwanto S T, Nurjazuli, Mursid R, 2015, Hubungan Paparan Timbal dalam Darab dengan Kejadian Hipertensi pada Pekerja Industri Pengecoran Logam di Ceper Klaten tabun 2015, Jurnal Kesehatan Lingkungan Indonesia, vol. 14 no. 2, hal. 35 - 39 .

Aminullah Y, Neni S, Wiratno, 2012, Pengaruh Kombinasi Vitamin C dan E Dosis Tinggi terhadap Sistem Hematopoetik Penderita Kanker Kepala dan Leher yang Mendapat Kemoterapi Cisplatin, Medica Hospitalia, vol. 1 (2), hal. 89 - 94.

Andriyanto, Aulia A M, Ietje W et al, 2014, Kemampuan berbagai Putih Telur Unggas sebagai Kelator dalam Mengatasi Keracunan Logam Berat Timbal, Jurnal Veteriner, vol. 15 no.3, hal. $406-410$

Asterina, Endrinaldi, 2014, Pengarub Timbal (Pb) Terhadap Kadar MDA Serum Tikus Putih Jantan, Jurnal FK Unand, hal. 531 - 535.

Aunurohim, Yulaipi S, 2013, Bioakumulasi Logam Berat Timbal $(\mathrm{Pb})$ dan Hubungannya dengan Laju Pertumbuban Ikan Mujair (Oreochromis mossambicus), Jurnal Sains dan Seni Pomits, vol. 2 no. 2, hal. 166 - 170.

Ayalogu O E, Ikhewuchi C C, Ikhewuchi C J et al, 2010, Proximate and Phytochemical Profile of Sansevieria liberica Gerome and Labroy, JASEM, vol. 14 (2), hal. 103 - 106.

Baldy C M, 2012, Gangguan Sel Darah Merah, In: Dewi A M, Huriawati H, Natalia S, et al, Patofiologi, edisi 6, EGC, Jakarta, hal. 255 267.

Batubara I, Latifah K D, Lela M Y, 2014, Sansevieria trifasciata Properties as Lead (II) Ion Biosorbent, In Press, vol. 18 no. 2, hal. 59 - 64.

Cahyati Y, Didik R S, Roni P et al, 2014, Pengaruh Pemberian Kombinasi Vitamin C dan E terbadap Jumlah Hemoglobin, Leukosit, dan Trombosit Pasca Iradiasi Sinar Gamma, Natural B, vol. 2 no. 3, hal. $289-295$.

Caroline W A, 2015, Penetapan Kadar Saponin pada Ektrak Daun Lidah Mertua (Sansevieria trifasciata Prain varietas S. Laurentii), Jurnal Ilmu dan Teknologi Kesehatan, vol. 2 no. 2, hal. $65-69$.

CDC, 2016, Lead, Elevated Blood Levels 2016 Case Definition, National Notifiable Disease Survilance System, viewed 31 January 2017, 
74 VOLUME 12 NOMOR 2 DESEMBER 2016

www.cdc.gov/nnds/conditions/leadelevated-blood-levels/case-defintion/2016/

Dewi Y S, Indri H, 2012, Kajian Efektivitas Daun Puring (Codiaeum varigatum) dan Lidah Mertua (Sanseviera tripasciata) dalam Menyerap Timbal di Udara Ambien, Jurnal Ilmiah Universitas Satya Negara Indonesia, vol. 5 no. 2, hal. 1 - 7 .

Djokomoejanto, Ag S, Iswari S et al, 2012, Hubungan antara Stress Oksidatif dengan Kadar Hemoglobin pada Penderita Thalassemia/Hbe, Jurnal Kedokteran Brawijaya, vol. 27 no. 1, hal. $38-42$.

Gusnita D, 2012, Pencemaran Logam Berat Timbal $\mathrm{Pb}$ ) di Udara dan Upaya Penghapusan Bensin Bertimbal, Berita Dirgantara, vol. 13 no. 3, hal. 95 - 101.

Guyton A C, John E H., 2014, Sel-Sel Darah Merah, Anemia, dan Polisistemia, In: Antonia Tanzil, Buku Ajar Fisiologi Kedokteran, edisi 12, Elsevier, Singapura, hal. 445 -454.

Hashemian A H, Haji A Y, 2013, The Effect of Occupational Exposure to Lead on Blood Hemoglobin Concentration in Workers of Kermanshah Oil Refinery, Irian Journal of Toxicology, vol. 6 no. 19, pp. 765 - 770.

Ikewuchi C C, Jude C I, 2009, Amino Acid, Mineral, and Vitamin Composition of Sansevieria liberica Gerome and Labroy, The Pacific Journal of Science and Technology, vol. 10 no. 1, pp. 477 - 482.

Iryani M, Tan M, 2011, Hubungan Kadar Timbel dalam Darah dengan Kadar Hemoglobin dan Hematokrit pada Petugas Pintu Tol Jagorawi, Jurnal Kesehatan Masyarakat Nasional, vol. 6 no. 1, hal. $35-41$.

Leksana E, 2015, Strategi Terapi cairan pada Debidrasi, CKD, vol. 42 no. 1, hal. 70-73.

Lubis B, Flora M P, Nelly R et al, 2013, Hubungan Keracunan Timbal dengan Anemia Defisiensi Besi pada Anak, Cermin Dunia Kedokteran-200, vol. 40 no. 1 , hal. $17-21$.

Margarita M L, 2014, Potensi Putib Telur Bebek dalam Mengatasi Keracunan Timbal Subakut, Institut Pertanian Bogor, hal. 1 - 11.

Murray R K, Granner D K, Rodwell V W, 2013, Porfirin \& Pigmen Empedu, In : Frans D, Leo R, Liena et al, Biokimia Harper, edisi 27, EGC, Jakarta, hal. 288 - 294.
Kurniawan A F, Amirul M, Sri E L et al, 2013, Pemanfaatan Ektrak Lidab Mertua (Sanseviera trifasciata laurentii) sebagai Bahan Penyerap Logam Toksik Timbal dalam Limbah Cair, Universitas Brawijaya.

Nurcahyo A D, Erista V A, Rika R et al, 2012, Pengaruh Lama Adsorbsi Ekstrak Sansevieria (Lidah Mertua) sebagai Adsorben Logan Ag dari Limbah Industri Perak di Kotagede, PELITA, vol. VIII no. 2, hal. 55 - 64.

Queljoe E, Astrid G S, Benny W, 2015, Perbedaan antara Efek Pemberian Vitamin $C$ dan Vitamin E terhadap Kualitas Spermatozoa Tikus Wistar (Rattus Norvegicus) Jantan setelah diberi Paparan Asap Rokok, Jurnal e-Biomedik, vol. 3 no. 1, hal $65-71$

Sayuti K, Rina Y, 2015, Antioksidan Alami dan Sintetik, Andalas University Press, Padang.

Suciani S, 2007, Kadar Timbal Dalam Darah Polisi Lalu Lintas dan Hubungannya dengan Kadar Hemoglobin, Phd thesis, Universitas Diponegoro, Semarang.

Swadaya N, 2008. Sansevieria, 200 Jenis Spektakuler, 400 Foto, Trubus, Jakarta. 